\title{
DUKUNGAN EMOSIONAL SUAMI DENGAN KEJADIAN ANEMIA PADA IBU HAMIL
}

\author{
Teti Rahmawati ${ }^{1}$ \\ ${ }^{1}$ Departemen Keperawatan Komunitas, STIKes Jayakarta, PKP DKI Jakarta
}

\begin{abstract}
ABSTRAK
Anemia dalam kehamilan yang disebabkan kurangnya zat besi di dalam tubuh dapat menimbulkan berbagai dampak terhadap ibu dan janin. Tujuan penelitian mengidentifikasi hubungan dukungan emosional suami dengan kejadian anemia pada ibu hamil. Desain penelitian adalah deskriptif analitik menggunakan pendekatan cross sectional terhadap 60 orang ibu hamil yang diambil dengan teknik purposive sampling. Hasil penelitian menunjukkan hubungan bermakna antara dukungan emosional suami dengan kejadian anemia pada ibu hamil dengan $\mathrm{p}$ value $=0,021$ dan nilai $\mathrm{OR}=4,583$. Rekomendasi penelitian adalah melakukan screening $\mathrm{Hb}$, promosi kesehatan, asuhan dan pelayanan melibatkan suami, dan meneliti dukungan emosional yang dibutuhkan ibu hamil dengan metode kualitatif.
\end{abstract}

Kata Kunci: Ibu Hamil, Dukungan Emosional Suami, Anemia

\begin{abstract}
Anemia in pregnancy is caused by lack of iron in the body can cause various effects to the mother and fetus. The aim of research to identify the relationship between the husband's emotional support with the prevalence of anemia in pregnant women. A quantitative descriptive analytic design with cross sectional approach was assigned in this study. Using purposive sampling technique, to 60 pregnant women. The results shows a significant relationship between the husband's emotional support with the prevalence of anemia in pregnant woman, with $p$ value 0,021 and $O R=4,583$. This study recommends $\mathrm{Hb}$ screening, the provision of health promotion, care and services which involve husbands, and further qualitative research on emotional support.
\end{abstract}

Keywords: Pregnant Women, Husband's Emotional Support, Anemia

\section{PENDAHULUAN}

Ibu hamil merupakan salah satu kelompok yang berisiko mengalami anemia. Hasil penelitian Pusponegoro (2012), Indonesia merupakan salah satu negara di Asia dengan angka kejadian anemia dalam kehamilan sebesar $51 \%$. Hasil RisKesDas (2013), menunjukkan $37,1 \%$ ibu hamil mengalami anemia dengan kadar $\mathrm{Hb}<11$ $\mathrm{gr} / \mathrm{dl}$. Prevalensi ibu hamil dengan anemia di Jawa Barat sebesar 13,5\% (DinKes Propinsi Jabar, 2010).

WHO (2010) memperkirakan 56\% dari seluruh jenis anemia disebabkan defisiensi besi. Prevalensi anemia defisiensi besi di dunia $20-50 \%$, di Indonesia antara $38 \%$ -
$71,5 \%$ atau rata-rata sekitar $63,5 \%$ (Kusmiati, 2011). Menurut Bobak, Lowdermilk, Jensen, dan Perry (2012) kurang zat besi merupakan penyebab anemia dalam kehamilan. Kekurangan zat besi dan perhatian terhadap ibu hamil menjadi faktor predisposisi anemia di Indonesia (Saifudin, 2006).

Anemia dalam kehamilan disebut "Potential Danger to Mother and Child", yang dapat menimbulkan berbagai dampak terhadap ibu, janin, keluarga, maupun masyarakat (DepKes, 2001). Laporan Susenas dan Survei DEPKES-UNICEF mengungkapkan dari 4 juta ibu hamil, setengahnya mengalami anemia gizi dan 1 
juta lainnya mengalami kekurangan energi kronis (Samhadi, 2008). Anemia pada saat kehamilan berkontribusi terhadap risiko kematian ibu melahirkan hingga 20\%. Melihat luasnya dampak yang ditimbulkan, maka pemerintah mencanangkan berbagai program untuk mencegah kejadian anemia pada ibu hamil.Program pemerintah yang dilakukan diantaranya memberikan tablet $\mathrm{Fe}$ (Fe sulfat $320 \mathrm{mg}$ dan asam folat $0,5 \mathrm{mg}$ ) untuk semua ibu hamil sebanyak 1 kali 1 tablet selama 90 hari disamping asupan gizi yang cukup (KemenKes RI, 2011). Pemberian tablet Fe dilakukan terintegrasi dengan pelayanan kunjungan ibu hamil (KemenKes RI, 2013).

Cakupan pemberian tablet $\mathrm{Fe}$ tersebar secara nasional. Cakupan Fe di Jawa Barat 73,87\% (DinKes Prov Jabar, 2014). Cakupan Fe di Depok 91,4\% (Profil Kesehatan Kota Depok, 2013). Meskipun secara persentasi cakupan Fe di Depok hampir mencapai target nasional tetapi berbanding terbalik dengan kondisi kesehatan ibu hamil, dengan ditemukannya $20 \%$ ibu hamil mengalami gejala $\mathrm{Hb}<8 \mathrm{gr} / \mathrm{dl}$, TD tinggi, dan odema nyata eklampsia (Profil Kesehatan Puskesmas Sukatani, 2013). Menurut Sinaga (2010), cakupan pemberian tablet Fe yang tinggi tidak akan berdampak pada penurunan anemia besi jika kepatuhan ibu hamil dalam menelan tablet besi masih rendah. Sesuai hasil penelitian Djamilus (2008), ibu hamil yang kurang patuh mengkonsumsi tablet $\mathrm{Fe}$ mempunyai risiko 2,429 kali lebih besar untuk mengalami anemia dibanding yang patuh konsumsi tablet Fe. Berdasarkan hasil penelitian Noverstiti (2012), responden yang mengalami anemia lebih banyak tidak patuh mengkonsumsi tablet $\mathrm{Fe}$ sesuai dengan aturan dan cara yang benar sebanyak $51 \%$. Rendahnya kepatuhan ibu mengkonsumsi tablet $\mathrm{Fe}$ dinilai sebagai penyebab utama tidak efektifnya program ini, dan salah satu faktor yang mempengaruhi adalah dukungan keluarga (Maisa, 2010).

\section{METODE PENELITIAN}

Penelitian ini merupakan penelitian kuantitatif non eksperimen dengan desain deskriptif analitik menggunakan pendekatan $\begin{array}{cccc}\text { Dukungan } & \text { keluarga } & \text { secara umum } \\ \text { menimbulkan } & \text { pengaruh } & \text { positif }\end{array}$ kesejahteraan fisik maupun psikis dan secara khusus mempengaruhi kesehatan selama masa kehamilan (Chapman, Hobfoll, \& Ritter, 2007). Menurut Taylor (2003), seseorang yang memiliki dukungan keluarga tinggi akan lebih berhasil menghadapi dan mengatasi masalahnya dibanding dengan yang tidak memiliki dukungan. Seseorang dengan dukungan keluarga buruk dapat meningkatkan stress dan prevalensi terjadinya penyakit (Hlebec, 2009). Dukungan keluarga dapat berupa dukungan sosial internal, seperti dukungan dari suami, istri atau saudara kandung (Friedman, Bowden, \& Jones, 2003).

DEPKES (2014) mengungkapkan upaya yang dilakukan untuk menurunkan kejadian anemia pada masa kehamilan adalah meningkatkan status gizi dan meningkatkan peran aktif suami. Sejalan dengan penelitian Indriasari (2005), dukungan suami perlu ditingkatkan untuk memotivasi ibu hamil agar lebih meningkatkan kepatuhan mengkonsumsi tablet $\mathrm{Fe}$ agar tidak mengalami anemia. Susanti (2010) mengatakan dukungan suami secara emosional adalah faktor yang penting untuk mencapai keberhasilan tugas perkembangan. Sebuah studi mengenai dukungan suami dan pengaruhnya terhadap kehamilan ibu menunjukkan mayoritas $(65,34 \%)$ dari responden suami memberikan dukungan baik secara emosional, sosial, ekonomis, dan informasi (Haobijam., Ludhiana, P. J., Usha, S., \& Usha, A, 2010).

Berdasarkan latar belakang diatas, penelitian ini akan mengidentifikasi "hubungan dukungan emosional suami dengan kejadian anemia pada ibu hamil di Wilayah Kelurahan Sukatani Kecamatan Tapos Kota Depok"

"cross sectional". Penelitian dilakukan di wilayah Kelurahan Sukatani Kecamatan Tapos Kota Depok pada bulan Mei. Populasi 
adalah seluruh ibu hamil, dengan sampel 60 responden yang diambil dengan menggunakan teknik purposive sampling.

Pengumpulan data menggunakan kuesioner dan screening $\mathrm{Hb}$, dilakukan oleh peneliti dengan tahapan memberikan penjelasan penelitian dan informed consent. Jika responden menyetujui untuk menjadi responden, selanjutnya akan menandatangani lembar persetujuan, pengisian lembar kuesioner diakhiri dengan screening $\mathrm{Hb}$, dan menanyakan usia kehamilan. Data yang diperoleh diolah

\section{HASIL PENELITIAN}

Ibu hamil di wilayah Kelurahan Sukatani $70 \%$ tidak mengalami anemia. Ibu hamil yang mengalami anemia $44 \%$ berada pada trimester III. Suami memberikan dukungan emosional dengan baik $68,33 \%$. Karakteristik suami sebagai pemberi dukungan 100\% berusia $\geq 20$ tahun, $81,67 \%$ memiliki pendidikan tinggi ( $\geq$ SMA), dan $56,67 \%$ memiliki pendapatan keluarga rendah (kurang dari UMK Depok tahun 2014 sebesar Rp. 2.397.000,-). Karakteristik ibu hamil 88,33\% berada direntang usia aman untuk bereproduksi ( $\geq 20$ tahun atau $\leq 35$ tahun), $76,7 \%$ berpendidikan tinggi ( $\geq$ SMA), dan $73,34 \%$ saat ini menjalani kehamilan $\leq 2$. Ibu hamil mengkonsumsi makanan dengan baik sebesar 55\%, dan $71,67 \%$ patuh mengkonsumsi suplemen zat besi (Fe).

Hasil penelitian menunjukkan ibu hamil yang mengalami anemia $16,67 \%$ mendapatkan dukungan emosional kurang dari $13,33 \%$ mendapatkan dukungan emosional baik. Perbedaan ini signifikan dengan nilai $p$ value $=0,021$, artinya terdapat hubungan bermakna antara dukungan emosional suami dengan kejadian anemia pada ibu hamil, dengan nilai $\mathrm{OR}=4,583$ $(1,399$ - 15,012), artinya ibu hamil yang mendapatkan dukungan emosional kurang mempunyai peluang 4,583 kali lebih besar untuk mengalami anemia dibandingkan yang mendapatkan dukungan emosional baik.

Anemia dalam kehamilan tidak dapat dipisahkan dengan perubahan fisiologis dan psikologis yang terjadi selama proses menggunakan metode komputer melalui tahapan editing, coding, data entry, dan cleaning. Tehnik analisis data menggunakan analisis deskriptif (univariat) dan analisis analitik (bivariat). Dalam penelitian ini, ibu hamil dikategorikan mengalami anemia bila $\mathrm{Hb}<11 \mathrm{gr} / \mathrm{dl}$ pada trimester 1 atau 3 serta $<$ $10.5 \mathrm{gr} / \mathrm{dl}$ pada trimester 2. Sedangkan dikategorikan mendapat dukungan emosional bila nilai yang diperoleh $\geq 39$ yang merupakan nilai median, karena data yang diperoleh berdistribusi tidak normal dengan nilai $p=0(p<0,05)$.

kehamilan. Pada saat hamil, secara fisiologis tubuh memerlukan darah lebih banyak hingga $30 \%$ daripada sebelum hamil (Proverawati,2011;Gibney,2008). Selain itu, ibu hamil juga mengalami berbagai perubahan psikologis, sehingga support system terutama yang diberikan oleh suami sangat diperlukan untuk membantu beradaptasi terhadap semua perubahan yang dialami, karena dukungan suami turut berperan penting dalam menentukan status kesehatan ibu (Keumalahayati,2008). Hal ini sejalan dengan penelitian Caho yang dilakukan tahun 2003 di New York bahwa seseorang dengan dukungan suami yang kurang dapat meningkatkan stress dan prevalensi terjadinya penyakit, termasuk anemia (Hlebec, 2009).

Hasil penelitian menunjukkan anemia paling banyak terjadi pada trimester 3 . Hal ini sesuai hasil penelitian Hoo Swie Tjiong yang menunjukkan $24,8 \%$ ibu hamil mengalami anemia pada trimester III (Manuaba, 2008). Menurut Tristiyanti (2006), meningkatnya kejadian anemia dengan bertambahnya umur kehamilan disebabkan terjadinya perubahan fisiologis pada kehamilan yang dimulai pada minggu ke-6 yaitu bertambahnya volume plasma dan mencapai puncaknya pada minggu ke-26 sehingga terjadi penurunan kadar haemoglobin.

Berdasarkan umur suami, semua suami ibu hamil dikategorikan mampu mengambil keputusan dan tindakan yang berpengaruh terhadap status kesehatan ibu dan janin. Hal 
ini sesuai dengan penelitian yang dilakukan Harnany (2006), faktor pengambilan keputusan dalam perawatan kehamilan tidak lepas dari pengaruh orang-orang disekitar ibu hamil, misalnya ibu kandung, ibu mertua, suami, nenek, serta kerabat ataupun tetangga. Menurut Notoatmodjo (2003), faktor usia dianggap optimal dalam mengambil keputusan adalah 20 tahun.

Kondisi ekonomi keluarga kurang dapat menyebabkan sulitnya mengakses pelayanan kesehatan, pemenuhan sandang, pangan, dan papan termasuk dalam memenuhi kebutuhan nutrisi dan pelayanan kesehatan ibu hamil (Stanhope \& Lancaster, 2012). Hasil penelitian menunjukkan sebagian besar keluarga ibu hamil memiliki pendapatan kurang dari UMK, hal ini dapat mengakibatkan ibu hamil berisiko mengalami masalah kesehatan (seperti anemia dalam kehamilan).

Menurut Notoatmodjo (2003), individu dengan pendidikan tinggi akan memiliki pemahaman yang lebih baik terhadap suatu masalah, sehingga lebih terbuka terhadap informasi, termasuk informasi kesehatan dalam memberikan dukungan keluarga. Hasil penelitian menunjukkan sebagian besar suami memiliki pendidikan tinggi, sehingga akan lebih mudah menerima, menyaring, dan mengimplementasikan informasi yang didapatnya termasuk informasi mengenai masalah anemia dalam kehamilan. Pengetahuan yang didapat suami akan diinformasikan kepada ibu hamil dan menjadi pengetahuan baru bagi ibu.

Hasil penelitian menunjukkan sebagian besar ibu hamil berada dalam rentang usia $\geq$ 20 tahun atau $\leq 35$ tahun. Sesuai hasil penelitian Bungsu (2012), ibu hamil usia $\geq 20$ tahun atau $\leq 35$ tahun sebagian besar tidak anemia dengan hasil uji statistik $\mathrm{p}$ value $=$ 0,142 artinya tidak ada hubungan secara signifikan dengan $\mathrm{OR}=0,51$ artinya ibu hamil usia $\geq 20$ tahun atau $\leq 35$ tahun dapat menurunkan risiko sebesar $51 \%$ untuk menderita anemia. Menurut Aghamohammadi dan Noortarijor (2011), umur merupakan salah satu faktor yang mempengaruhi terjadinya risiko anemia pada ibu hamil, berkaitan dengan alat-alat reproduksi. Hal ini berkaitan dengan kesiapan seorang wanita untuk hamil yang meliputi aspek fisik, emosi, psikologi, sosial, dan ekonomi (Gebremedhin \& Enquselassie, 2011).

Hasil penelitian menunjukkan sebagian besar ibu hamil memiliki pendidikan tinggi. Hal ini sesuai dengan penelitian yang dilakukan Silalahi (2007), menunjukkan adanya hubungan antara tingkat pendidikan ibu dengan kejadian anemia pada kehamilan. Tingkat pendidikan yang tinggi dapat mempengaruhi perilaku kesehatan seseorang termasuk kemampuan dalam memilih makanan yang sehat (Sulistyoningsih, 2011).

Hasil penelitian menunjukkan, sebagian besar ibu hamil saat ini menjalani kehamilan $\leq 2$. Hasil penelitian ini sesuai dengan penelitian Gebremedhin dan Enquselassie (2011), paritas memiliki dampak yang jelas pada prevalensi anemia, wanita dengan lebih dari dua kehamilan memiliki tingkat signifikan lebih tinggi untuk terjadi anemia. Penelitian Silalahi (2007) menunjukkan adanya hubungan antara paritas dengan kejadian anemia pada kehamilan. Hal ini menunjukkan bahwa semakin sering ibu melahirkan, maka resiko menderita anemia akan semakin besar karena terlalu sering hamil dapat menguras cadangan zat gizi dalam tubuh ibu (Arisman, 2010). Hasil penelitian ini tidak sesuai dengan hasil penelitian Noverstiti (2012), tidak adanya hubungan antara paritas dengan kejadian anemia. $\mathrm{Hal}$ ini kemungkinan disebabkan oleh faktor lain yang mempengaruhi kondisi ibu hamil seperti: sikap, tindakan, dan jarak kehamilan sebelumnya.

Hasil penelitian menunjukkan, sebagian besar ibu hamil memenuhi asupan makanan dengan baik. Hal ini tidak sejalan dengan penelitian Craemer, Zimmermann, Huch, R., dan Huch, A, (2006), menyatakan selama kehamilan wanita kurang mengkonsumsi makanan yang mengandung zat besi baik secara kualitas maupun kuantitas. Ketidakadekuatan asupan nutrisi menyebabkan ibu hamil rawan mengalami kekurangan gizi (Notoatmojo, 2003). Kurang gizi merupakan salah satu penyebab 
terjadinya risiko anemia pada masa kehamilan (Bobak, Lowdermilk, Jensen, \& Perry, 2012).

Hasil penelitian menunjukkan sebagian besar ibu hamil patuh mengkonsumsi suplemen zat besi. Sesuai hasil penelitian Bungsu (2012), menyatakan sebagian besar ibu hamil patuh mengkonsumsi Fe. Tetapi tidak sesuai dengan penelitian Amanda (2012), mengungkapkan sebagian besar ibu hamil tidak patuh mengkonsumsi tablet zat besi. Hal ini kemungkinan disebabkan oleh kriteria responden. Responden pada penelitian ini adalah semua ibu hamil dalam semua trimester sedangkan responden dalam penelitian Amanda adalah semua responden berada pada kehamilan trimester III.

Hasil penelitian menunjukkan sebagian besar ibu hamil mendapat dukungan emosional baik. Hasil ini sesuai dengan hasil penelitian Wirawati (2014). Tetapi, sebagian besar ibu hamil yang mengalami anemia mendapatkan dukungan emosional yang kurang.

Berdasarkan hasil analisis bivariat, secara statistik, bentuk dukungan emosional mempunyai hubungan yang bermakna terhadap kejadian anemia pada ibu hamil. Sesuai dengan penelitian yang dilakukan oleh Wirawati (2014), terdapat hubungan antara dukungan emosional keluarga dengan kadar $\mathrm{Hb}$ ibu hamil, artinya bentuk dukungan

\section{KESIMPULAN}

Terdapat hubungan antara dukungan emosional yang diberikan suami dengan kejadian anemia pada ibu hamil. Hasil penelitian ini dapat menjadi masukan bagi pemberi kebijakkan (DinKes) maupun pemberi pelayanan (Puskesmas) untuk merancang program yang dapat meningkatkan pemahaman suami untuk

\section{REFERENSI}

Aghamohammadi, A. \& Noortarijor, M. 2011. Maternal age as a risk factor for pregnancy outcomes: Maternal, foetal and neonatal complication. African Journal of Pharmacy and Pharmacology emosional keluarga yang kurang dalam pemenuhan nutrisi ibu hamil memiliki peluang 5,2 kali untuk mendapatkan kadar $\mathrm{Hb}$ tidak normal pada ibu hamil. Hasil penelitian ini juga menunjukkan dukungan emosional secara statistik bermakna karena memiliki nilai $\mathrm{p}$ value $=0,021$, artinya terdapat hubungan antara dukungan emosional suami dengan kejadian anemia pada ibu hamil.

Susanti (2010) mengatakan dukungan suami secara emosional adalah faktor yang penting untuk mencapai keberhasilan tugas perkembangan. Senada dengan pernyataan Friedman, Bowden, dan Jones (2003), terpenuhinya dukungan emosional dalam keluarga akan meningkatkan kualitas manusia, stabilitas kepribadian, perilaku, dan harga diri anggota keluarga. Artinya, semakin baik dukungan emosional yang diperoleh ibu hamil akan semakin baik kualitas hidup, harga diri, dan perilaku ibu hamil dalam memperhatikan kesehatannya sehingga tidak mengalami masalah kesehatan termasuk anemia.

Dukungan emosional kurang yang diberikan suami lebih ke arah perhatian, hal ini terlihat dari hasil kuesioner yaitu suami jarang mengingatkan jadwal periksa kehamilan dan jarang mengingatkan untuk tidak lupa makan yang mengandung nutrisi baik.

berperan aktif dalam memberikan dukungan terhadap ibu hamil terutama dukungan emosional yang berdampak terhadap kesehatan ibu hamil. Kegiatan yang dilakukan dapat berupa SHG, sehingga suami dapat bertukar pikiran dan memperoleh pengalaman dari orang lain.

Amanda, F. 2012. Faktor-faktor yang berhubungan dengan kepatuhan ibu hamil dalam mengkonsumsi tablet zat besi di wilayah kerja Puskesmas Tanah 
Garam Kota Solok Tahun 2012. Tesis UNAND.

Arisman. 2010. Gizi dalam Daur Kehidupan. Jakarta: EGC

Badan Penelitian dan Pengembangan Kesehatan Kementerian Kesehatan RI. 2013. Riset kesehatan dasar: Riskesdas 2013. Jakarta: Kemenkes RI Bobak, Lowdermilk, Jensen, \& Perry. 2012. Buku Ajar Keperawatan Maternitas. Alih Bahsa: Maria W A. Wijayarini, Peter I. Editor Edisi Bahasa Indonesia, Renata Komalasari. Edisi 4. Jakarta: EGC

Bungsu, P. 2012. Pengaruh Kadar Tanin pada Teh Celup terhadap Anemia Gizi Besi pada Ibu Hamil di UPT Puskesmas Citeureup Kab Bogor. Tesis. Epidemiologi. FKM UI

Chapman, H.A., Hobfoll, S.E., \& Ritter, C. 2007. Partner's stress underestimation lead to women distress: A study of pregnant inner-city women. Journal of Personality and Social Psychology

Craemer, B., Zimmermann, R., Huch R., \& Huch A. 2006. Use of recombinant human erythropoietin in combination with parenteral iron in the treatment of postpartum anaemia. European Journal of Clinical Investigation

DepKes RI., 2014. Lindungi Ibu dan Bayi dengan Imunisasi. http://www.depkes.go.id , 2001. Program Penanggulangan Anemia Gizi pada Wanita Usia Subur (WUS); (Safe Motherhood Project: A Partnership and Family Approach). Direktorat Gizi Masyarakat. Jakarta: Direktorat Jenderal Bina Kesehatan Masyarakat Depkes

DinKes Prov Jabar. 2014. Maternal Health Report 2014. Diunduh dari http://diskes.jabarprov.go.id pada Rabu, 21 Januari 2015 pukul 20.10 WIB

DinKes Kota Depok. 2013. Profil Kesehatan Kota Depok Tahun 2013

Djamilus, H. 2008. Faktor Risiko Kejadian Anemia Ibu Hamil Di Wilayah Kerja Puskesmas Bogor.

Friedman, M.M., Bowden, V.R., \& Jones, E.G. 2003. Family Nursing: Theory and
Practice. Ed. 5. Philadelphia: Appleton \& lange

Gebremedhin, S., \& Enquselassie F. 2011. Correlates of anemia among women of reproductive age in Ethiopia: Evidence from Ethiopian DHS 2005. Ethiop Jurnal Health.

Gibney, M. J. 2008. Gizi Kesehatan Masyarakat. Terjemahan. Jakarta: EGC

Haobijam., Ludhiana, P. J., Usha, S., \& Usha, A. 2010. An exploratory study to assess the Family support and its effect on Outcome of Pregnancy in terms of Maternal and Neonatal health in a selected Hospital. Nursing and Midwifery Research Journal.

Harnany, A.S. 2006. Pengaruh Tabu Makanan, Tingkat Kecukupan Gizi, Konsumsi Tablet Besi dan Teh terhadap Kadar Hemoglobin Ibu Hamil di Kota Pekalongan. Tesis IKM UNDIP

Hlebec, V., Maja, M., \& Kogovsek, T. 2009. Social Support Network and Received Support at Stressful Events. Metodoloskizvezki

Indriasari. 2005. Efektivitas Program Supplementasi Tablet Besi Pada Ibu Hamil Pengunjung ANC klinik di Nam Phong Khon Kaen, Thailand.

KemenKes RI., 2013. Profil Kesehatan Indonesia 2012. Jakarta: Kementerian Kesehatan 2013. RISKESDAS 2013. Jakarta 2011. Buku Saku Millennium Development Goals (MDG's) di Bidang Kesehatan Tahun 2011-2015. Biro Perencanaan dan Anggaran Kementerian Kesehatan Republik Indonesia

Keumalahayati. 2008. Dukungan Suami terhadap Kesiapan Ibu Primigravida Menghadapi Persalinan: Studi Grounded Theory. Tesis UI.

Kusmiati, S., 2011. Studi Validitas dan Reliabilitas Hasil Pemeriksaan Kadar Hemoglobin Dengan Metoda Sahli dan Metoda Talqvist Untuk Deteksi Anemia Pada Ibu Hamil Di Puskesmas Wilayah Bojonagara Kota Bandung. Tesis. UGM. 
Maisa, E.A. 2010. Hubungan Antara Dukungan Keluarga dengan Kepatuhan Konsumsi tablet Fe pada Ibu Hamil di Wilayah kerja Puskesmas Nanggalo Kecamatan Nanggalo Kota Padang Tahun 2010. Tesis FK UNAND.

Manuaba, I. B. G. 2008. Ilmu kebidanan, Penyakit Kandungan, dan Keluarga Berencana untuk Pendidikan Bidan. Jakarta: EGC

Notoatmodjo, S. 2003. Pendidikan dan Perilaku Kesehatan. Jakarta: Rineka Cipta.

Noverstiti, E. 2012. Faktor-Faktor yang Berhubungan dengan Kejadian Anemia Pada Ibu Hamil Trimester III Di Wilayah Kerja Puskesmas Air Dingin Kota Padang Tahun 2012. Tesis. FKM. UNAND.

Patimah. 2005. Pola Konsumsi lbu Hamil dan Hubungannya Dengan kejadian Anemia Defisiensi Besi Pada Ibu Hamil. Jurnal Sains \& Teknologi.

Pemerintahan Daerah Kota Depok. 2013. Profil Kesehatan Kota Depok Tahun 2013.

Profil Kesehatan Puskesmas Sukatani. 2013

Proverawati, A. 2011. Anemia dan Anemia Kehamilan. Yogyakarta: Nuha Medika.

Pusponegoro. 2013. Prevalensi anemia di Indonesia tinggi. Lampung Post.

Diakses dari http://lampost.co pada sabtu 10 jan 2015 jam 11.00

Saifudin. 2006. Buku Acuan Nasional Pelayanan Kesehatan Maternal dan Neonatal. Edisi I Cetakan Keempat. Jakarta: Yayasan Bina Pustaka

Sinaga, E. 2010. Hubungan pengetahuan, sikap dan tindakan pencegahan dengan kejadian anemia pada ibu hamil Trimester III yang berkunjung kepuskesmas Medan Deli tahun 2009. Tesis Fakultas Kesehatan Masyarakat Universitas Sumatera Utara Medan

Stanhope, M., \& Lancaster, J. 2012. Public Health Nursing Population Centered Health Care in The Community, $8^{\text {th }}$ ed. Missouri: Elsevier

Sulistyoningsih, H. 2011. Gizi Untuk Kesehatan Ibu dan Anak. Edisi Pertama.
Cetakan Pertama. Yogyakarta: Graha IImu.

Tayor, R.B. 2003. Family Medicine: Principles and Practice. Sixth edition. New York: Springer-Verlag. 